FIU Law Review

Volume 11

Number 2 Separation of Powers

Article 13

Spring 2016

\title{
Coming Out of the Venire: Sexual Orientation Discrimination and the Peremptory Challenge
}

Jessica Satinoff

Florida International University College of Law

Follow this and additional works at: https://ecollections.law.fiu.edu/lawreview

Part of the Civil Rights and Discrimination Commons, and the Constitutional Law Commons

Online ISSN: 2643-7759

\section{Recommended Citation}

Jessica Satinoff, Coming Out of the Venire: Sexual Orientation Discrimination and the Peremptory Challenge, 11 FIU L. Rev. 463 (2016).

DOI: https://dx.doi.org/10.25148/lawrev.11.2.13

This Comment is brought to you for free and open access by eCollections. It has been accepted for inclusion in FIU Law Review by an authorized editor of eCollections. For more information, please contact lisdavis@fiu.edu. 


\title{
Coming Out of the Venire: Sexual Orientation Discrimination and the Peremptory Challenge
}

\author{
Jessica Satinoff
}

We, the people, declare today that the most evident of truths-that all of us are created equal-is the star that guides us still; just as it guided our forebears through Seneca Falls, and Selma, and Stonewall.... It is now our generation's task to carry on what those pioneers began... Our journey is not complete until our gay brothers and sisters are treated like anyone else under the law.

-President Barack Obama ${ }^{1}$

\section{INTRODUCTION}

The United States Constitution provides that all criminal defendants are entitled to a speedy and public trial before a fair and impartial jury. ${ }^{2}$ In order to ensure that the accused receive an impartial jury, peremptory challenges allow a party to remove potentially biased members of the jury pool during voir dire. ${ }^{3}$ Voir dire allows lawyers to inquire into the prospective jurors' attitudes, beliefs, morals, and views related to issues that will likely arise during trial. ${ }^{4}$ Historically, there have only been two limitations on a party's ability to strike a potential juror through the peremptory challenge: race and gender. ${ }^{5}$ One would be hard-pressed to contend that sexual orientation should not be a third. ${ }^{6}$

Batson v. Kentucky, decided in 1986, first established that peremptory challenges may not be exercised to remove a prospective juror solely based

* J.D. candidate, 2016, Florida International University College of Law; B.A., 2012, University of Central Florida. I would like to thank my mother, Miryam, for her unconditional support and encouragement. I would also like to thank Professor Howard Wasserman for his guidance throughout the writing process. Finally, a special thanks to the editors of the FIU Law Review for publishing my Note.

1 President Barack Obama, Inaugural Address (Jan. 21, 2013).

2 U.S. CONST. amend. VI.

3 See Jason Matthew Lamb, The Constitution, Peremptory Challenges, and United States v. Martinez-Salazar, 22 WhitTIER L. REV. 843, 843 (2001).

4 See id.

5 See generally Batson v. Kentucky, 476 U.S. 79 (1986); J.E.B. v. Alabama ex rel. T.B., 511 U.S. 127 (1994).

6 See Giovanna Shay, In the Box: Voir Dire on LGBT Issues in Changing Times, 37 HARV. J.L. \& GENDER 407, 451 (2014). 
on race. ${ }^{7}$ In 1994, the Court established the second limitation on a party's ability to strike a potential juror through peremptory challenges. ${ }^{8}$ In J.E.B. v. Alabama, the Court held that gender was also an unconstitutional proxy for determining a juror's competence and impartiality. ${ }^{9}$ The Court reasoned that gender discrimination during voir dire perpetuates invidious and antiquated stereotypes regarding the aptitude of men and women. ${ }^{10}$ To date, Batson has only applied to discrimination during voir dire based on race and gender. ${ }^{11}$ In recent years, however, sexual orientation discrimination has generated significant legal headway. ${ }^{12}$ In United States $v$. Windsor, for example, the Supreme Court struck down the federal Defense of Marriage Act's (DOMA) ban on recognizing same-sex marriages. ${ }^{13}$ The Court affirmed the Second Circuit's judgment, which applied heightened scrutiny to DOMA's classification based on sexual orientation. ${ }^{14}$

Although the Court never expressly stated that it was applying heightened judicial review, its ruling indicates implicit application of heightened scrutiny. ${ }^{15}$ This is evinced by the majority's position on the meaning of the constitutional guarantee of equality- "that a bare congressional desire to harm a politically unpopular group cannot justify disparate treatment of the group." "16 The Court went on to explain that discrimination of such an unusual character requires careful consideration, which indicates its application of a standard higher than rational basis review to scrutinize sexual orientation classifications. ${ }^{17}$ Several courts, including the Ninth Circuit, have held that the logic and reasoning of Windsor implicitly requires the application of heightened scrutiny to equal protection claims involving sexual orientation. ${ }^{18}$

Federal circuit courts of appeals have expressed opposing views regarding the applicability of Batson to peremptory strikes based on sexual orientation. The Ninth Circuit, in SmithKline Beecham Corporation $v$. Abbott Laboratories, recently held that peremptory strikes used to discriminate on the basis of sexual orientation may be challenged under

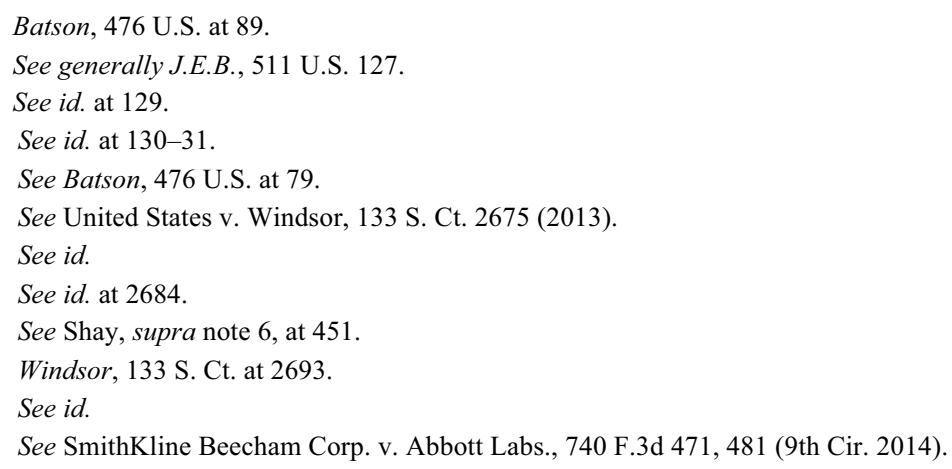


Batson. ${ }^{19}$ Yet, the Eighth Circuit, in United States v. Ehrmann, and the Eleventh Circuit, in Sneed v. Florida Department of Corrections, expressed serious doubt as to whether Batson's scope extends beyond race and gender. $^{20}$

Batson should be extended to sexual orientation discrimination because such discrimination is simply a form of gender discrimination, which is already prohibited by the Court's decision in J.E.B. v. Alabama. ${ }^{21}$ If conduct is prohibited when engaged in by a person of one gender, yet permitted when engaged in by a person of the opposite gender, then, by definition, such a prohibition is discriminatorily based on sex and traditional gender roles. ${ }^{22}$ In the alternative, Batson challenges should be applicable to discrimination based on sexual orientation because of the similarities between gender and sexual orientation, as well as the equal protection implications found in Windsor. ${ }^{23}$ The Ninth Circuit holding in SmithKline, while not binding on other circuits, is highly persuasive and should be adopted by all other circuits in light of the Windsor decision. Because the Court in Windsor implied that sexual orientation is subject to heightened scrutiny review, peremptory strikes on this basis should be afforded the same protections as race and gender during voir dire. ${ }^{24}$

This Note will examine the equal protection implications of Windsor and consider the rationale for extending the Batson analysis to sexual orientation discrimination. Part II of this Note will provide a history of peremptory challenges in the United States and the evolution of the Batson analysis. This Part will also address the various competing interests that should be considered, including the rights of the litigant and the excluded juror. Part III will discuss sexual orientation discrimination jurisprudence, the standard of judicial review for sexual orientation, and the rationale for applying heightened scrutiny to classifications that single out individuals for disparate treatment based on their sexual orientation. Part IV will analyze peremptory challenges in relation to sexual orientation and the circuit split among various federal circuit courts of appeals regarding the applicability of Batson to peremptory challenges solely based on sexual orientation. This Part will also discuss the rationale supporting the extension of Batson to sexual orientation. Part $\mathrm{V}$ will provide

19 See id. at 471.

20 See United States v. Ehrmann, 421 F.3d 774 (8th Cir. 2005); see also Sneed v. Fla. Dep't. of Corr., 496 Fed. App'x 20 (11th Cir. 2012).

21 See Andrew Koppelman, Why Discrimination Against Lesbians and Gay Men Is Sex Discrimination, 69 N.Y.U.L. REV. 197, 198 (1994).

22 See id. at 208.

23 See Jill Elaine Hasday, Women's Exclusion from the Constitutional Canon, 2013 U. ILL. L. REV. 1715, 1731-32 (2013).

24 See SmithKline, 740 F.3d at 471. 
recommendations to eliminate sexual orientation discrimination during voir dire and conclude with potential consequences if the Supreme Court does not adopt these recommendations.

\section{BACKGROUND}

\section{A. History of the Peremptory Challenge}

The Sixth Amendment to the United States Constitution guarantees a trial by an impartial jury. ${ }^{25}$ To impanel such a jury, lawyers engage in the process of voir dire, during which each lawyer is afforded the opportunity to question jurors and decide which prospective jurors will be selected to hear the case. ${ }^{26}$ Prior to the commencement of trial, each party's lawyer attempts to identify potential jurors that may be biased and have such jurors struck, either for cause or through a peremptory challenge. ${ }^{27}$ Parties may exercise an unlimited amount of challenges for cause, which are used to excuse prospective jurors who are unlikely to be fair and impartial during the case being heard. ${ }^{28}$ In order to exercise a challenge for cause, a party must provide the court with an explanation for challenging the juror, and the judge must then decide whether the prospective juror should be removed based on his or her inability to be fair and impartial. ${ }^{29}$

The peremptory challenge, as distinguished from the challenge for cause, allows a party to strike a prospective juror from the venire without providing the court any justification for the strike. ${ }^{30}$ Essentially, a party exercises a peremptory challenge when the party believes that a prospective juror will be biased for reasons that cannot be articulated to the court. ${ }^{31}$ While a party may typically exercise peremptory challenges without cause, the Equal Protection Clause prohibits parties from exercising peremptory challenges solely on account of race or an assumption that racial minorities as a whole will be unable to serve as impartial jurors in a case against a racial minority defendant. ${ }^{32}$ The peremptory challenge was further limited based on the Court's finding that gender has no bearing on an individual's

25 U.S. CONST. amend. VI.

26 See James J. Gobert et Al., Jury Selection: The Law, Art AND SCIEnCE Of Selecting A JURY $§ 10: 1$ (Westlaw).

27 See id.

28 See Kenneth J. Melilli, Batson in Practice: What We Have Learned About Batson and Peremptory Challenges, 71 NoTRE DAME L. REV. 447, 447 (1996).

29 See id.

30 See Coburn R. Beck, The Current State of the Peremptory Challenge, 39 WM. \& MARY L. REV. 961, 963 (1998).

31 See Kathryn Ann Barry, Striking Back Against Homophobia: Prohibiting Peremptory Strikes Based on Sexual Orientation, 16 BERKELEY WOMEN’s L.J. 157, 160 (2001).

32 Batson v. Kentucky, 476 U.S. 79, 89 (1986). 
competence and ability to serve as an impartial juror. ${ }^{33}$ Today, a party may exercise a peremptory challenge to remove prospective jurors for any reason, aside from the individual's race or gender. ${ }^{34}$

The number of peremptory challenges each party may exercise is defined by statute and, therefore, varies by jurisdiction and case type. ${ }^{35}$ In federal criminal cases, courts allow twenty peremptory challenges per party in a capital case, six peremptory challenges for the government and ten for the defendant in all other felony cases, and three peremptory challenges per party in misdemeanor cases. ${ }^{36}$ In all civil cases, federal courts allow each party to exercise three peremptory challenges. ${ }^{37}$ Most states have enacted statutes that permit parties to exercise peremptory challenges in similar numbers and type as the federal courts. ${ }^{38}$

Originally, the peremptory challenge was established to eliminate unqualified and biased members from the jury pool. ${ }^{39}$ Peremptories date back to Roman times and were implemented under English common law as well. ${ }^{40}$ The British peremptory challenge was brought to the early American colonies and was subsequently adopted by all states. ${ }^{41}$ Initially, most states regarded the peremptory challenge as a right of the defendant and were slow to extend this right to the prosecution. ${ }^{42}$ Since its inception, the peremptory challenge has been rooted in the tradition of the United States and has served as an indispensable tool for impaneling an impartial jury. ${ }^{43}$

The peremptory challenge ensures fairness during jury selection, complements challenges for cause, and safeguards the voir dire process from biased jurors. ${ }^{44}$ It serves to eliminate extreme bias and prejudice on both sides of a case, as well as to "assure the parties that the jurors before whom they try the case will decide on the basis of the evidence placed before them, and not otherwise." ${ }^{45}$ In her concurring opinion in J.E.B. v. Alabama, Justice O'Connor opined that the significance of the peremptory challenge is evinced by its establishment during the time of Blackstone and

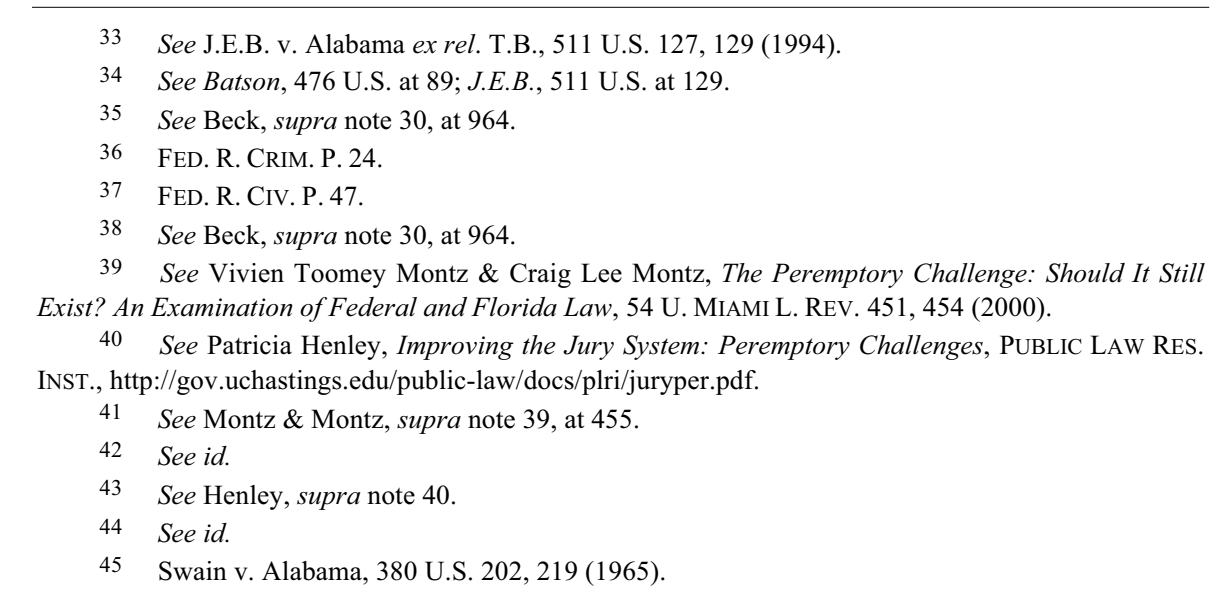


its continued endurance in all the states. ${ }^{46}$ Traditionally, peremptory challenges allowed parties to exclude a prospective juror for any reason; however, the Court's evolving jurisprudence has placed limitations on the peremptory challenge. ${ }^{47}$ Today, parties may object to a peremptory challenge if they believe that the opposing party discriminatorily exercised the peremptory challenge to exclude the member from the venire solely based on race or gender. ${ }^{48}$

\section{B. Evolution of Batson v. Kentucky}

Batson, a landmark Supreme Court case, established the framework that prevents peremptory challenges from being used discriminatorily during voir dire. ${ }^{49}$ In Batson, an African-American man was accused of committing burglary and receiving stolen goods. ${ }^{50}$ During jury selection, the prosecutor used his peremptory challenges to strike all four AfricanAmerican individuals, resulting in a jury comprised solely of white individuals. ${ }^{51}$ Batson was found guilty on both counts and appealed his conviction, arguing, inter alia, that the prosecutor discriminatorily exercised peremptory challenges to remove individuals from the venire solely because of their race. ${ }^{52}$ The Supreme Court of Kentucky affirmed his conviction, holding that a defendant must demonstrate systematic exclusion of a group of prospective jurors in order to allege lack of a fair cross-section of individuals serving on the jury. ${ }^{53}$

The Supreme Court of the United States held that if the trial court found that the facts established prima facie purposeful discrimination, and the prosecutor did not provide a neutral explanation for his action, Batson's conviction must be reversed. ${ }^{54}$ The Court reasoned that the Equal Protection Clause forbids the prosecutor from striking potential jurors solely based on their race because it denies a defendant "the protection that a trial by jury is intended to secure." ${ }^{55}$ The Court highlighted its prior efforts to eradicate invidious racial discrimination during voir dire and noted that such discrimination harms not only the accused, but also the community at

46 See J.E.B. v. Alabama ex rel. T.B., 511 U.S. 127, 147 (1994) (O’Connor, J., concurring).

47 See Esther J. Last, Peremptory Challenges to Jurors Based on Sexual Orientation: Preempting Discrimination by Court Rule, 48 IND. L. REV. 313, 315-16 (2014).

48 See id.

49 See Batson v. Kentucky, 476 U.S. 79 (1986).

50 See id. at 82.

51 See id. at 83.

52 See id.

53 See id. at 84.

54 See id. at 100.

55 Id. at 86. 
large. ${ }^{56}$ Ultimately, the Court held that peremptory challenges may not be used to strike a prospective juror solely on the basis of race because practices that intentionally bar individuals from serving on juries due to their race "undermine public confidence in the fairness of our system of justice." $" 57$

Today, the Batson challenge is commonly understood as one party's objection that an opposing party has exercised a peremptory challenge to remove a prospective juror from the venire exclusively on account of race or gender. ${ }^{58}$ The principle of Batson now applies in both criminal and civil cases. ${ }^{59}$ Procedurally, a party may raise a Batson challenge as soon as it believes the opposing party has exercised a peremptory challenge discriminatorily to remove a potential juror. ${ }^{60}$ Once the jury has been impaneled, asserting a Batson challenge would be superfluous because the excluded juror can no longer serve on that jury. ${ }^{61}$ If the court denies a party's Batson challenge, this issue may be raised on appeal, so long as the record has been adequately preserved for appellate review. ${ }^{62}$

The legal significance of the Court's decision in Batson is two-fold. First, the Court established a three-part inquiry to determine whether impermissible discrimination has occurred against a potential juror during voir dire ${ }^{63}$ In order to establish that such discrimination has occurred, the party challenging the peremptory strike must first establish a prima facie case of intentional discrimination. ${ }^{64}$ The striking party must then provide a neutral, nondiscriminatory reason for the strike. ${ }^{65}$ Finally, the court must decide, based on the record, whether the party raising the challenge has demonstrated intentional discrimination. ${ }^{66}$

Second, Batson established the elements necessary to make a prima facie showing of intentional discrimination during jury selection. First, the challenging party must demonstrate that he or she is a member of an identifiable group and that the striking party has exercised peremptory challenges to excuse members of the challenging party's group from the

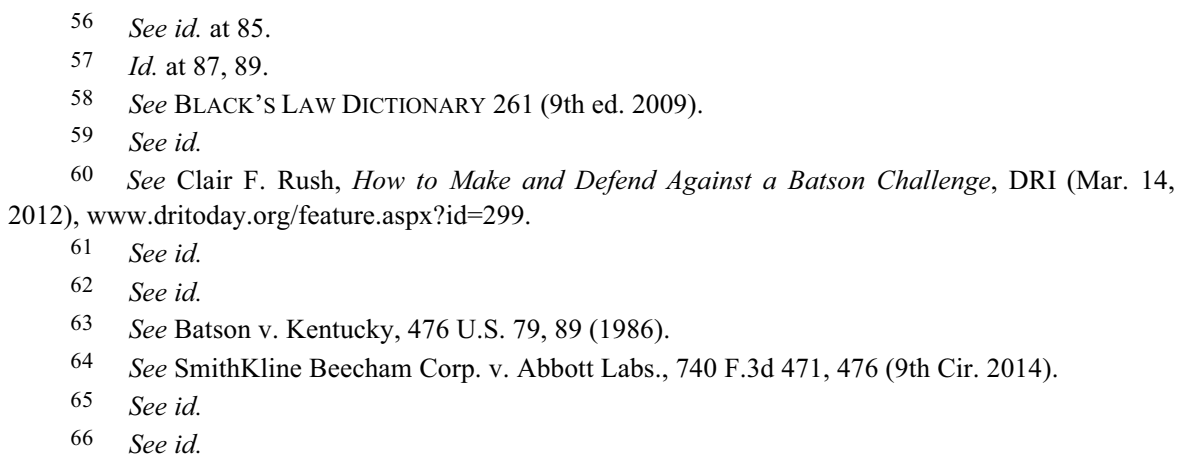


jury pool. ${ }^{67}$ Second, the challenging party must prove that the facts and surrounding circumstances raise an inference that the striking party actually did exercise peremptory challenges to remove the prospective jurors exclusively based on their membership in the cognizable group. ${ }^{68}$

Under the Equal Protection Clause, a defendant may also raise a Batson challenge to the exclusion of jurors based on race, regardless of whether the defendant and the prospective jurors are members of the same race. ${ }^{69}$ In Powers v. Ohio, the defendant, a white male, objected when the prosecution exercised six of its ten peremptory challenges to remove black individuals from the jury pool. ${ }^{70}$ The trial court overruled Powers' objections, and he was convicted of murder. ${ }^{71}$ The Supreme Court held that a defendant may raise a third-party equal protection claim for jurors excused solely based on their race. ${ }^{72}$

Almost a decade after Batson, J.E.B. v. Alabama extended the threepart analysis to gender-based discrimination. ${ }^{73}$ In J.E.B., Alabama filed a petition on behalf of the mother of a minor child to establish paternity and child support against J.E.B. ${ }^{74}$ The State exercised nine of its ten peremptory challenges to excuse male jurors, and J.E.B. exercised all but one of his challenges to excuse female jurors. ${ }^{75}$ The resulting jury was comprised solely of female jurors. ${ }^{76}$ The jury found J.E.B. to be the minor child's father, and the court ordered him to pay child support. ${ }^{77}$ The Supreme Court held that "gender, like race, is an unconstitutional proxy for juror competence and impartiality." 78 The Court noted that the logic of Batson also forbids purposeful discrimination on account of gender because such discrimination perpetuates "invidious, archaic, and overbroad stereotypes about the relative abilities of men and women," in contravention to the Equal Protection Clause. ${ }^{79}$ The Court explained that excluding cognizable groups from serving on juries is inconsistent with the constitutional construct of trial by jury. ${ }^{80}$

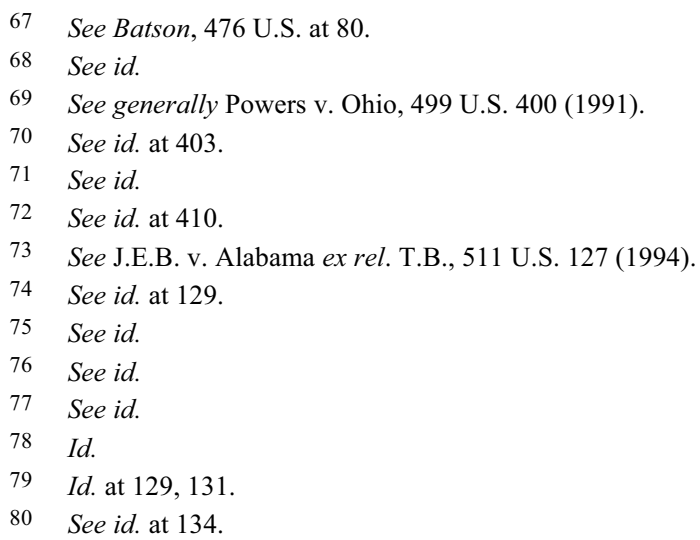


Gender discrimination is a relatively recent phenomenon because women were historically precluded from serving on juries. ${ }^{81}$ The Court observed that, while the discrimination that women and racial minorities have experienced in the United States have not been identical, the similarities between the groups' experiences support the extension of the Batson analysis to discrimination based on gender. ${ }^{82}$ The Court recognized that women, much like African-Americans, have experienced a history of exclusion and discrimination in American society ${ }^{83}$ As it did in Batson, the Court affirmed the notion that discrimination during jury selection harms not only the litigants, but also the community and prospective jurors who are prohibited from participating in the judicial process. ${ }^{84}$ Ultimately, the Court held that gender-based discrimination during voir dire does not further the State's interest in achieving a fair and impartial jury. ${ }^{85}$

While the Supreme Court of the United States has long recognized the peremptory challenge as a fundamental instrument in obtaining an impartial jury, not all justices have taken the same position. ${ }^{86}$ In his dissent in J.E.B. v. Alabama, Justice Scalia criticized the majority's position that peremptory challenges based on any cognizable group subject to heightened scrutiny are inconsistent with the constitutional guarantees of equal protection. ${ }^{87}$ Scalia argued that because all classes are subject to peremptory challenges, essentially no class is denied equal protection. ${ }^{88}$ Strongly opposing the Court's reasoning in J.E.B., Scalia noted that for every male that was excused by the government, the petitioner excused a female. ${ }^{89}$ Therefore, Scalia concluded that there was no gender discrimination, because both genders were being excused through peremptory challenges evenhandedly. ${ }^{90}$

Scalia would have likely opposed extending Batson to sexual orientation, just as he opposed applying it to gender, because peremptory challenges have existed in conjunction with the Equal Protection Clause for over a century. ${ }^{91}$ Because peremptory challenges are used to excuse both heterosexuals and homosexuals equally, Scalia would have likely argued that neither group is denied equal protection under the Fourteenth

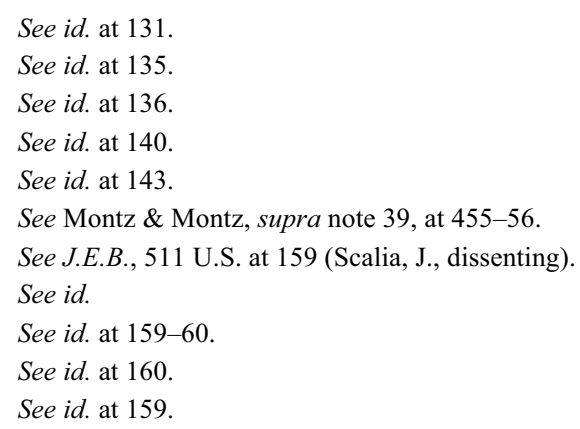


Amendment. ${ }^{92}$ This argument, however, fails to consider the emphasis that our society has placed on eliminating invidious discrimination entirely, as exemplified by the Thirteenth, Fourteenth, and Fifteenth Amendments to the United States Constitution. ${ }^{93}$

\section{Balancing Interests During Discriminatory Peremptory Challenges}

In Batson and its progeny, the Court has had to balance several interests in prohibiting the discriminatory exercise of peremptory challenges during voir dire. ${ }^{94}$ The first, and most significant interest, is the defendant or civil litigant's constitutional right to a fair trial before an impartial jury. ${ }^{95}$ The Court has held that the State violates the Equal Protection Clause when members of the defendant's race have been intentionally excluded from serving on the jury. ${ }^{96}$ Such discrimination violates a defendant's equal protection rights because it contravenes the very safeguard that a trial by jury is intended to provide. ${ }^{97}$

Second, when a prospective juror is excused through a peremptory challenge, the juror's rights are at stake as well. ${ }^{98}$ The Court has recognized that preventing a prospective juror from participating in the administration of justice solely based on race or gender is unconstitutional discrimination against the excluded juror. ${ }^{99}$ Allowing citizens to contribute to the judicial process has long been regarded as a fundamental justification for preserving the trial by jury system in the United States. ${ }^{100}$ Courts have recognized that jurors have privacy interests during jury selection, and have begun to impose greater restrictions on the scope of voir dire questioning based on such privacy interests. ${ }^{101}$

Finally, the Court has often commented on the far-reaching consequences of discriminatory practices during jury selection. ${ }^{102}$ In addition to the harm that such discrimination inflicts upon litigants and excluded jurors, discriminatory peremptory challenges undermine public

\footnotetext{
See id. at 160.

See generally U.S. CONST. amends. XIII, XIV, XV.

94 See Maureen A. Howard, Taking the High Road: Why Prosecutors Should Voluntarily Waive Peremptory Challenges, 23 GeO. J. LeGAL ETHICS 369, 401-06 (2010).

95 See Batson v. Kentucky, 476 U.S. 79, 108 (1986).

96 See id. at 85.

97 See id. at 86.

98 See id.

99 See id. at 87; see also J.E.B. v. Alabama ex rel. T.B., 511 U.S. 127, 127 (1994).

100 See Powers v. Ohio, 499 U.S. 400, 406 (1991).

101 See Paul R. Lynd, Juror Sexual Orientation: The Fair Cross-Section Requirement, Privacy, Challenges for Cause, and Peremptories, 46 UCLA L. REV. 231, 258 (1998).

102 See Batson, 476 U.S. at 87.
} 
confidence in the fairness of the judicial system. ${ }^{103}$ Ultimately, discrimination during jury selection "offends the dignity of persons and the integrity of the courts."

\section{SEXUAL ORIENTATION DisCRIMINATION}

\section{A. Sexual Orientation Discrimination Jurisprudence}

The lesbian, gay, bisexual, and transgender (LGBT) community has experienced both private and public discrimination throughout history. ${ }^{105}$ While private discrimination is difficult to remedy, public discrimination that singles out sexual minorities based on their sexual orientation should be eliminated. ${ }^{106}$ Despite the constitutional guarantees of equality, the LGBT community is a minority group that is still subject to governmentsanctioned discrimination today. ${ }^{107}$ While society as a whole has shifted toward acceptance of homosexuality, many individuals continue to harbor negative attitudes toward sexual minorities, which harm the LGBT community in public ways. ${ }^{108}$

The Supreme Court first addressed discrimination based on sexual orientation approximately thirty years ago in Bowers v. Hardwick. ${ }^{109}$ In Bowers, the Court upheld a state statute that criminalized sodomy, reasoning that disapproval of homosexual conduct was deeply rooted in the tradition of our country, and that the State had a legitimate interest in prohibiting such conduct. ${ }^{110}$ This case is illustrative of society's historical moral disapproval of sexual minorities and the history of discrimination they have endured. ${ }^{111}$ Approximately ten years later, there was a sea change in the Court's sexual orientation discrimination jurisprudence. ${ }^{12}$ In Romer v. Evans, the Court invalidated a state constitutional amendment that sought to prohibit government protection of sexual orientation. ${ }^{113}$ The Court implicitly authorized state antidiscrimination statutes to include sexual orientation as a protected class, but only applied rational basis review in

103 See Batson, 476 U.S. at 87; see also J.E.B., 511 U.S. at 140.

104 Powers, 499 U.S. at 402.

105 See Eric A. Roberts, Heightened Scrutiny Under the Equal Protection Clause: A Remedy to Discrimination Based on Sexual Orientation, 42 DRAKE L. REV. 485, 486 (1993).

106 See id.

107 See id.

108 See id. at 498.

109 See generally Bowers v. Hardwick, 478 U.S. 186 (1986), overruled by Lawrence v. Texas, 539 U.S. 558 (2003).

110 See Andrea L. Claus, The Sex Less Scrutinized: The Case for Suspect Classification for Sexual Orientation, 5 PHOENIX L. REV. 151, 156 (2011).

111 See id.

112 See id. at 157.

113 See id. 
doing so. ${ }^{114}$ Scholars have argued that the Court's treatment of sexual minorities as a class under the Equal Protection Clause prompted several states to amend their antidiscrimination statutes to include sexual orientation as a protected class. ${ }^{115}$

The Court eventually overruled Bowers in the notable case of Lawrence v. Texas. ${ }^{116}$ Lawrence was convicted for engaging in "deviate sexual intercourse" with a member of the same sex, in violation of a state statute outlawing same-sex sexual conduct. ${ }^{117}$ Although Lawrence was decided on due process, rather than equal protection grounds, it represents the first Supreme Court ruling in which the Court defined sexual minorities as being a cognizable group, which supports the application of heightened judicial review. ${ }^{118}$ The progression of the Supreme Court's jurisprudence regarding sexual orientation discrimination demonstrates the shift in public attitudes toward sexual minorities. ${ }^{119}$ The Bowers decision reflected society's historical moral disapproval of homosexuality, while Romer and Lawrence evinced society's shifting views toward acceptance of homosexuality. ${ }^{120}$ Despite this societal shift, sexual minorities still experience discriminatory treatment in housing, public accommodations, and the workplace today. ${ }^{121}$ This discrimination reflects the need to provide heightened protection for sexual orientation classifications under the Equal Protection Clause.

\section{B. Standard of Judicial Review for Sexual Orientation}

Traditionally, discrimination based on sexual orientation was subject to rational basis judicial review by the Supreme Court. ${ }^{122}$ Although the Court has heard several cases pertaining to sexual orientation discrimination, it has generally applied rational basis review, ${ }^{123}$ or declined to explicitly state what level of judicial review it was applying. ${ }^{124}$ Because of the ambiguity created by recent Supreme Court decisions, it is helpful to consider the emerging trend of state courts applying heightened scrutiny to

114 See id.

115 See id. at 157-58.

116 See id. at 158.

117 Id.

118 See id.

119 See id. at 161.

120 See id.

121 See id.

122 See generally Bowers v. Hardwick, 478 U.S. 186 (1986), overruled by Lawrence v. Texas, 539 U.S. 558 (2003); Romer v. Evans, 517 U.S. 620 (1996).

123 See generally Bowers, 478 U.S. 186; Romer, 517 U.S. 620.

124 See United States v. Windsor, 133 S. Ct. 2675 (2013); Obergefell v. Hodges, 135 S. Ct. 2584 (2015). 
classifications that discriminate based on sexual orientation. ${ }^{125}$ According to a fifty-state survey provided by the American Bar Association, at least five states protect jurors from discrimination based on their sexual orientation, as of $2013 .{ }^{126}$

In 2008, the California Supreme Court became the first high court in the country to hold that classifications discriminating based on sexual orientation deserve the same protections under the law as classifications based on race and gender. ${ }^{127}$ In reaching its decision, the court explained that there was no persuasive reason to apply a less rigorous standard for statutes that discriminate on the basis of sexual orientation than the standard applied to statutes that classify on the basis of race or gender. ${ }^{128}$ The court reasoned that

[b]ecause sexual orientation, like gender, race, or religion, is a characteristic that frequently has been the basis for biased and improperly stereotypical treatment and that generally bears no relation to an individual's ability to perform or contribute to society, it is appropriate for courts to evaluate with great care and with considerable skepticism any statute that embodies such a classification. ${ }^{129}$

Although this case was later superseded by constitutional amendment, it demonstrates the paradigm shift in societal views toward classifications based on sexual orientation. ${ }^{130}$

Subsequently, the Connecticut Supreme Court also held that sexual orientation is a quasi-suspect class under the Connecticut Constitution. ${ }^{131}$ In its analysis, the Connecticut Supreme Court delineated factors for determining whether a classification is suspect or quasi-suspect, including whether a class has experienced a history of discrimination, whether the characteristic associated with that class is related to an individual's ability to participate and contribute to society, whether the characteristic is central to an individual's personal identity, and whether the class is a minority or lacks political power. ${ }^{132}$ The court found that members of the LGBT community are a minority class that have suffered a history of

125 See, e.g., In re Marriage Cases, 43 Cal. 4th 757, 783-84 (2008); Varnum v. Brien, 763 N.W.2d 862, 896 (Iowa 2009); Griego v. Oliver, 2014-NMSC-003, 316 P.3d 865, 884 (N.M. 2013).

126 See Shmuel Bushwick, Excluding Gay Jurors After Windsor, AM. BAR Ass'N SEC. OF Litig. (Nov. 7, 2013), http://apps.americanbar.org/litigation/committees/lgbt/articles/fall2013-1113-excludinggay-jurors-after-windsor.html.

127 See In re Marriage Cases, 43 Cal. 4th at 783-84.

128 See id.

129 Id. at 757 (emphasis added).

130 See Shay, supra note 6, at 411.

131 See Kerrigan v. Comm'r of Pub. Health, 289 Conn. 135, 141 (2008).

132 See id. at 165-66. 
discrimination and held that laws discriminating on the basis of sexual orientation are subject to heightened judicial scrutiny. ${ }^{133}$

High courts across the United States began applying heightened judicial review to classifications based on sexual orientation, much like California and Connecticut. ${ }^{134}$ In 2009, the Supreme Court of Iowa held that classifications discriminating on the basis of sexual orientation are subject to heightened scrutiny, without specifying whether it was applying intermediate or strict scrutiny. ${ }^{135}$ The court observed that members of the LGBT community have suffered from centuries of public discrimination. ${ }^{136}$ Accordingly, the court held that in order to prevent the perpetuation of historical prejudice and stereotyping, laws that single out individuals for disparate treatment based on sexual orientation are subject to heightened judicial review. ${ }^{137}$

In 2013, the Supreme Court of New Mexico held that intermediate scrutiny should be applied to classifications based on sexual orientation because the LGBT community is an identifiable class that has suffered from a history of intentional discrimination and has not been able to protect itself from such discrimination through the legal system. ${ }^{138}$ The court reasoned that because an individual's sexual orientation is so essential to one's identity, it would be inappropriate to require an individual to alter his or her sexual orientation to avoid discrimination. ${ }^{139}$

While many state supreme courts have held that classifications on the basis of sexual orientation are subject to heightened scrutiny, this position has not been uniformly adopted by all high courts across the country. The Washington Supreme Court, for example, held that sexual orientation discrimination is not subject to heightened scrutiny. ${ }^{140}$ The court refused to apply heightened scrutiny because sexual orientation has not been declared immutable, and because the implementation of provisions providing protections to the LGBT community in Washington demonstrates that they are not powerless, but are actually exercising substantial political power. ${ }^{141}$ The Maryland Court of Appeals similarly held that classifications based on sexual orientation are not subject to heightened scrutiny. ${ }^{142}$

133 See id. at 179.

134 See, e.g., Varnum v. Brien, 763 N.W.2d 862 (Iowa 2009); see also Griego v. Oliver, 316 P.3d 865 (N.M. 2013).

135 See, e.g., Varnum, 763 N.W.2d 862; see also Griego, 316 P.3d 865.

136 See Varnum, 763 N.W.2d at 896.

137 See id.

138 See Griego, 316 P.3d at 884.

139 See id.

140 See Andersen v. King County, 138 P.3d 963, 975 (2006).

141 See id. at 974-75.

142 See Conaway v. Deane, 932 A.2d 571, 605 (2007). 
In a press release from the Attorney General prior to the Supreme Court ruling in United States $v$. Windsor, the Executive Branch adopted the position that sexual orientation classifications should be subject to heightened review. ${ }^{143}$ In evaluating the aforementioned factors articulated by the Supreme Court, the Attorney General first recognized that there has been a significant history of purposeful discrimination against the LGBT community, by both the government and private entities. ${ }^{144}$ Such discrimination is rooted in prejudice and stereotypes that continue to harm the LGBT community today. ${ }^{145}$ Second, the Attorney General noted that although sexual orientation is not readily apparent, it is widely accepted within the scientific community to be an immutable characteristic. ${ }^{146}$ Courts have held that because it is so central to one's identity, it would be unfair to require an individual to conceal their sexual orientation in order to avoid discriminatory treatment. ${ }^{147}$

Third, laws enacted by the government that promote discrimination based on sexual orientation demonstrate that members of the LGBT community lack political power and the "ability to attract the [favorable] attention of the lawmakers." 148 Such laws include those at issue in Romer and Lawrence, as well as discrimination based on sexual orientation in the military and workplace. ${ }^{149}$ Finally, sexual orientation "bears no relation to ability to perform or contribute to society." "150 This is supported by the repeal of discriminatory legislation regarding sexual orientation, the evolution of the Court's sexual orientation jurisprudence, and social science studies explaining that an individual's sexual orientation does not hinder his or her ability to contribute to society. ${ }^{151}$

In 2013, the Supreme Court ultimately struck down DOMA in United States $v$. Windsor. ${ }^{152}$ The Court held that DOMA violates the Equal Protection Clause, as applied to the Federal Government through the Fifth Amendment. ${ }^{153}$ In its reasoning, the Court explained that "DOMA's principal effect is to identify a subset of state-sanctioned marriages and

143 See Letter from the Attorney General to Congress on Litigation Involving the Defense of Marriage Act, DEP'T OF JUST. (Feb. 23, 2011), www.justice.gov/opa/pr/letter-attorney-general-congresslitigation-involving-defense-marriage-act.
144 See id.
145 See id.
146 See id.
147 See id.
$148 I d$.
149 See id.
150 Id. (citing Frontiero v. Richardson, 411 U.S. 677, 686 (1973) (plurality)).
151 See DEP'T OF JUSTICE, supra note 143.
152 See United States v. Windsor, 133 S. Ct. 2675 (2013).
153 See id. at 2683. 
make them unequal. The principal purpose is to impose inequality, not for other reasons like governmental efficiency." "154 The Court went on to note that DOMA diminishes the significance of state-sanctioned marriages and tells both the same-sex couples, and society, that their otherwise legitimate marriages are not worthy of recognition by the federal government. ${ }^{155}$ By placing same-sex couples in second-tier marriages, DOMA burdened their lives in public ways. ${ }^{156}$

The Supreme Court invalidated the federal statute because there was no legitimate purpose that outweighed the practical purpose and effect of disparaging and injuring those individuals whom the State of New York, through its marriage laws, sought to protect. ${ }^{157}$ The Court stated that the obvious purpose of DOMA was "to impose a disadvantage, a separate status, and so a stigma upon all who enter into same-sex marriages made lawful by the unquestioned authority of the States."158 Although the Court never expressly stated the level of judicial review it was applying, its language suggests an implicit adoption of heightened scrutiny for classifications based on sexual orientation. ${ }^{159}$ In its reasoning, the Court explained that the constitutional guarantee of equality ensures that a bare congressional desire to harm a political minority class cannot justify unequal treatment of that class. ${ }^{160}$ The Court implied that classifications based on sexual orientation should be subject to heightened judicial review, stating that discrimination of such an unusual character requires careful consideration in determining whether a law is motivated by an improper purpose. ${ }^{161}$ Relying on the Court's decision in Windsor, the Ninth Circuit subsequently held that classifications based on sexual orientation are subject to a heightened standard of judicial review. ${ }^{162}$

Many scholars have taken the position that sexual orientation is a suspect or quasi-suspect class and, thus, should be subject to heightened judicial review. ${ }^{163}$ Some scholars have reasoned that sexual orientation should be treated as a suspect classification because like race, sexual

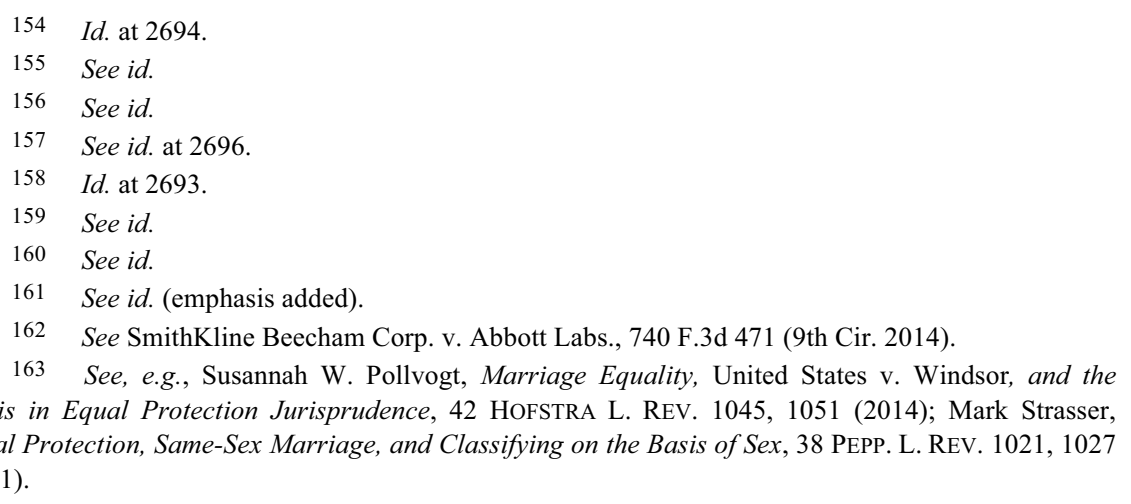


orientation has no bearing on an individual's ability to contribute to society and, therefore, should not serve as the basis for a discriminatory law. ${ }^{164}$ This argument is based on several lower courts' reliance on a suspect classification analysis, despite the Supreme Court's reluctance to explicitly do so. ${ }^{165}$

Additionally, scholars have recognized that the application of heightened scrutiny to classifications based on sexual orientation, and explicit acknowledgement of such application, will resolve the inconsistencies between lower court decisions and the Supreme Court holdings in Romer, Lawrence, and Windsor. ${ }^{166}$ Because the Supreme Court has not explicitly articulated the level of judicial review that should apply to sexual orientation classifications, it is helpful to consider the position that lower courts have taken. ${ }^{167}$ In applying the factors that the Court has established to determine whether a classification should be afforded heightened scrutiny, courts have consistently found that all four factors support the application of heightened scrutiny. ${ }^{168}$

\section{Rationale for Applying Heightened Scrutiny}

Although the Supreme Court has not explicitly stated the appropriate standard of judicial review for classifications based on sexual orientation, it has established the factors that should be considered when determining whether heightened scrutiny applies. ${ }^{169}$ The criteria that the Court examines are whether the group has suffered from a history of discrimination, whether individuals "exhibit obvious, immutable, or distinguishing characteristics that define them as a discrete group," whether the group is a minority or lacks political power, and whether the characteristics singling out the group for disparate treatment have little relation to legitimate policy objectives or to an individual's "ability to perform or contribute to society." $" 170$

The LGBT community has undoubtedly suffered from a history of discrimination. ${ }^{171}$ The first statute prohibiting homosexual conduct dates

164 See Pollvogt, supra note 163, at 1053

165 See id. at 1051.

166 See Jeremy B. Smith, The Flaws of Rational Basis with Bite: Why the Supreme Court Should Acknowledge Its Application of Heightened Scrutiny to Classifications Based on Sexual Orientation, 73 FORDHAM L. REV. 2769, 2813 (2005).

167 See Kendra LaCour, License to Discriminate: How a Washington Florist Is Making the Case for Applying Intermediate Scrutiny to Sexual Orientation, 38 SEATTLE U.L. REV. 107, 124 (2014).

168 See id.

169 See DEP'T OF JUSTICE, supra note 143.

170 Id. (citing Bowen v. Gilliard, 483 U.S. 587, 602-03 (1987)); City of Cleburne v. Cleburne Living Ctr. 473 U.S. 432, 441-42 (1985).

171 See Roberts, supra note 105, at 498. 
back to the time of King Henry VIII of England. ${ }^{172}$ The statute provided that any homosexual act was "an infamous crime against nature," and was considered a disgrace to the human race. ${ }^{173}$ Sexual minorities have been persecuted throughout history, most notably during World War II. ${ }^{174}$ In Germany, sexual minorities were sent to Nazi concentration camps and sentenced to death, simply because of their sexual orientation. ${ }^{175}$ While such large-scale persecution may not occur today, the LGBT community still experiences discrimination in public ways. ${ }^{176}$ Many individuals continue to exhibit hostile attitudes toward sexual minorities and perpetuate false stereotypes that harm the LGBT community. ${ }^{177}$

The military, for example, has acknowledged that, "homosexuals have historically been the object of pernicious and sustained hostility."178 Additionally, the general public has perpetuated negative attitudes toward the LGBT community through their use of offensive language to describe members of the group. ${ }^{179}$ Words such as "queer," "homo," "fag," and "dyke" are derogatory terms used to convey moral and social inferiority of sexual minorities. ${ }^{180}$ The false stereotypes regarding the LGBT community further demonstrate the history of discrimination that sexual minorities have experienced. ${ }^{181}$ Such stereotypes include the erroneous beliefs that sexual minorities suffer from mental illness, are likely to molest children, or can alter the sexual orientation of individuals with whom they interact. ${ }^{182}$ These false stereotypes have resulted in both public and private discrimination of individuals because of their sexual orientation. ${ }^{183}$ Based on the history of discrimination that members of the LGBT community have experienced, this factor in the Court's analysis supports the application of heightened scrutiny to sexual orientation discrimination.

The second factor that the Court examines is whether individuals exhibit obvious, immutable, or distinguishing characteristics that define them as a discrete group. ${ }^{184}$ Although homosexuality was long regarded as a

$\begin{array}{ll}172 & \text { See id. } \\ 173 & \text { Id. } \\ 174 & \text { See id. } \\ 175 & \text { See id. } \\ 176 & \text { See id. } \\ 177 & \text { See id. } \\ 178 & \text { Id. at } 499 . \\ 179 & \text { See id. } \\ 180 & \text { Id. } \\ 181 & \text { See id. at 500. } \\ 182 & \text { See id. } \\ 183 & \text { See id. } \\ 184 & \text { DEP'T OF JUSTICE, }\end{array}$

184 DEP'T OF JUSTICE, supra note 143. 
psychological disorder by the American Psychiatric Association ${ }^{185}$ and society at large, it is now generally accepted that homosexuality is not a psychological or emotional illness that can be cured. ${ }^{186}$ Scientific studies suggest that sexual orientation is not a matter of choice, but rather a matter of genetics. ${ }^{187}$ Some researchers have concluded that neurological and hormonal factors during the gestation of a fetus are responsible for determining an individual's sexual orientation. ${ }^{188}$

While some scientists still question whether sexual orientation is biological in nature, it should nevertheless be treated as "immutable" for the purposes of this heightened scrutiny analysis. ${ }^{189}$ Some scholars have argued that the immutability requirement refers to traits "so central to a person's identity that it would be abhorrent for government to penalize a person for refusing to change them." 190 This proposition is supported by the Court's decision to apply heightened scrutiny to other classifications that are not strictly immutable. ${ }^{191}$ For example, the Court has applied heightened judicial review to gender classifications, despite the fact that individuals can alter their sex, thus rendering the trait mutable. ${ }^{192}$ Furthermore, sexual minorities' preference to engage in sexual relations with members of the same sex is a sufficiently obvious and distinguishing characteristic that defines members of the LGBT community as a discrete group. ${ }^{193}$

The third factor, whether the LGBT community is a minority or politically powerless, has been a topic of debate among scholars. ${ }^{194}$ The lack of political power among members of the LGBT community is evinced by the government-sanctioned discrimination that sexual minorities have experienced. ${ }^{195}$ Such discrimination and moral disapproval has caused many sexual minorities to conceal their sexual orientation. ${ }^{196}$ As a result, the LGBT community has historically been unable to express its opposition to discriminatory legislation in any meaningful capacity. ${ }^{197}$ The continued existence of discriminatory laws, and the unwillingness of political leaders

\footnotetext{
185 See Roberts, supra note 105 , at 500.

186 See id. at 504; see also John Charles Hayes, The Tradition of Prejudice Versus the Principle of Equality: Homosexuals and Heightened Equal Protection Scrutiny After Bowers v. Hardwick, 31 B.C. L. REV. 375, 380 (1990).

$\begin{array}{ll}187 & \text { See Roberts, supra } \text { note } 105 \text {, at } 506 . \\ 188 & \text { See id. } \\ 189 & \text { Id. } \\ 190 & \text { Id. } \\ 191 & \text { See id. } \\ 192 & \text { See id. } \\ 193 & \text { See id. at } 507 . \\ 194 & \text { See id. } \\ 195 & \text { See id. } \\ 196 & \text { See id. } \\ 197 & \text { See id. at } 508 .\end{array}$
}


to repeal them, demonstrates the lack of political power that sexual minorities possess. ${ }^{198}$ While some scholars have taken the position that the LGBT community has gained significant political power in recent years, there are still many pieces of discriminatory legislation that oppress the LGBT community. ${ }^{199}$ Such government-sanctioned legislation is prevalent in various arenas, such as public employment, the military, family law, and criminal law. ${ }^{200}$

The final factor that the Court considers when determining if a group warrants heightened protection under the Equal Protection Clause is whether the characteristics distinguishing the group have little relation to legitimate policy objectives or to an individual's ability to perform or contribute to society. ${ }^{201}$ While this factor may have been disputed years ago, it is established today that one's sexual orientation does not inhibit his or her ability to contribute to society. ${ }^{202}$ This factor requires little discussion, as it is generally accepted that sexual minorities live happy, well-adjusted lives, just as heterosexual individuals do. ${ }^{203}$ An individual's sexual orientation, much like one's race or gender, is unrelated to his or her ability to contribute to society. ${ }^{204}$

Based on the research related to the aforementioned factors, the argument in favor of applying heightened judicial review to classifications based on sexual orientation is compelling. ${ }^{205}$ Although the Supreme Court has yet to articulate that classifications based on sexual orientation are subject to heightened scrutiny, the analysis of the factors supports this independent conclusion, and many courts have evaluated the criteria and recognized the need for heightened protection. ${ }^{206}$

\section{Peremptory Challenges And Sexual Orientation}

\section{A. Federal Circuit Courts of Appeals Application}

Federal Circuit Courts of Appeals are currently split regarding the applicability of Batson to sexual orientation discrimination. The Ninth Circuit has adopted the position that peremptory strikes used to discriminate on the basis of sexual orientation may be challenged under Batson. ${ }^{207}$ In

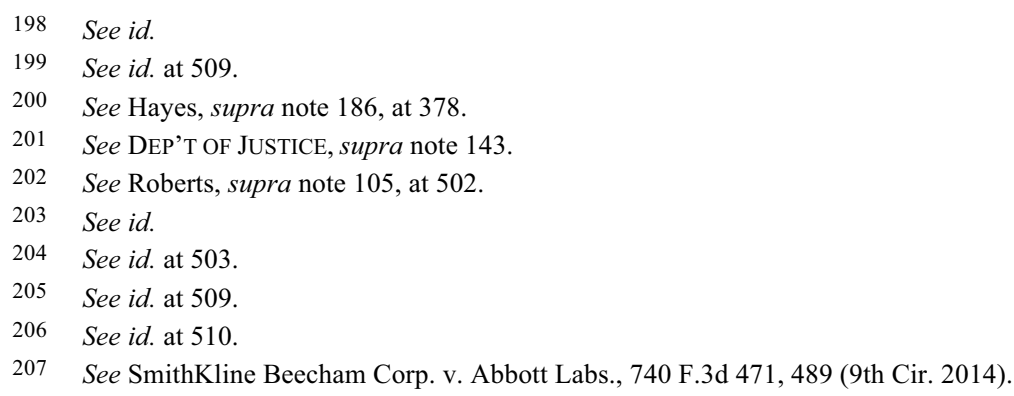


SmithKline Beecham Corporation, a suit was brought against Abbott Laboratories that contained claims relating to a licensing agreement and the pricing of HIV medications. ${ }^{208}$ During voir dire, Abbott used its first peremptory strike to remove the only self-identified gay member of the jury pool. ${ }^{209}$ SmithKline attempted to challenge the strike under Batson, but the district judge denied the challenge. ${ }^{210}$

Applying the three-part inquiry established in Batson, it is apparent that impermissible discrimination against a potential juror during voir dire had occurred. SmithKline provided adequate evidence to establish a prima facie case of purposeful discrimination. ${ }^{211}$ First, SmithKline produced evidence that the excluded juror is a member of an identifiable class because: (1) the juror was the only self-identified gay member of the jury pool, and (2) the subject matter of the litigation was related to HIV, which is a controversial issue within the gay community. ${ }^{212}$ SmithKline became aware of the potential juror's sexual orientation during voir dire because the juror voluntarily revealed that he had a "partner" and referred to his partner several times by using the masculine pronoun, "he." 213 The court noted that when jury pools contain little diversity, a strike of the sole member of the minority group is a pertinent consideration when determining whether a prima facie case has been established. ${ }^{214}$ Thus, the court in SmithKline considered the fact that the prospective juror was the only self-identified gay member in the jury pool when making its determination. ${ }^{215}$

Second, Abbott exercised a peremptory challenge against this prospective juror. ${ }^{216}$ Finally, the totality of the circumstances raised an inference that the challenge was motivated by the juror's sexual orientation. $^{217}$ The court found reason to infer that Abbott struck the potential juror based on his sexual orientation because of the fear that he would be biased by the concern in the LGBT community regarding Abbott's decision to increase the price of its HIV medications. ${ }^{218}$ The Supreme Court has held that when the characteristic of the juror coincides with the nature of the litigation, the potential for a discriminatory challenge

$\begin{array}{ll}208 & \text { See id. at } 474 . \\ 209 & \text { See id. } \\ 210 & \text { See id. } \\ 211 & \text { See id. at } 476 . \\ 212 & \text { See id. } \\ 213 & \text { Id. at } 474 . \\ 214 & \text { See id. at } 476 . \\ 215 & \text { See id. } \\ 216 & \text { See id. } \\ 217 & \text { See id. } \\ 218 & \text { See id. }\end{array}$


based on that characteristic increases substantially. ${ }^{219}$

In SmithKline, because the litigation involved a subject matter that is of great concern to the LGBT community, the potential for relying on impermissible stereotypes during jury selection significantly increased. ${ }^{220}$ After SmithKline produced evidence to support the three-part inquiry established in Batson, the court concluded that the party successfully raised an inference of purposeful discrimination. ${ }^{221}$ After SmithKline established a prima facie case of intentional discrimination, Abbott did not offer any nondiscriminatory reason for excusing the juror, even when provided the opportunity to do so by the court. ${ }^{222}$ The court determined that SmithKline successfully made a showing of purposeful discrimination and that the juror was struck only because of his sexual orientation. ${ }^{223}$

Relying on the Supreme Court decision in Windsor, the Ninth Circuit found that because classifications based on sexual orientation are subject to heightened scrutiny, the Equal Protection Clause prohibits discrimination based on sexual orientation during voir dire. ${ }^{224}$ In making this determination, the court analogized the analysis in SmithKline to that of the Ninth Circuit's interpretation of another landmark Supreme Court decision, Lawrence v. Texas. ${ }^{225}$ The Ninth Circuit, in Witt v. Department of Air Force, balanced three factors in interpreting the Supreme Court's decision in Lawrence to implicitly require a heightened level of judicial scrutiny with respect to substantive due process. ${ }^{226}$

In applying those three factors to SmithKline, the Ninth Circuit first observed that the Court in Windsor, like that in Lawrence, did not examine the potential rational reasons for the law in question, as it normally would for classifications that are subject to rational basis judicial review. ${ }^{227}$ Because the Court in Windsor did not consider hypothetical rationales for the law, but rather evaluated the essence, stated purpose, and actual effect of the law, the decision seems to suggest that the Court was applying heightened judicial review. ${ }^{228}$

As to Witt's second factor, the court stated that "[j]ust as Lawrence required that a legitimate state interest justify the harm imposed by the Texas law, the critical part of Windsor begins by demanding that

$\begin{array}{ll}219 & \text { See id. } \\ 220 & \text { See id. at } 477 . \\ 221 & \text { See id. } \\ 222 & \text { See id. } \\ 223 & \text { See id. at } 478 . \\ 224 & \text { See id. at } 489 . \\ 225 & \text { See id. at } 480 . \\ 226 & \text { See id. } \\ 227 & \text { See id. at } 481 . \\ 228 & \text { See id. at } 481-82 .\end{array}$


Congress's purpose 'justify disparate treatment of the group.",229 The court concluded that if the Supreme Court was applying rational basis review, it would not have identified a legitimate state interest to justify the unequal treatment of sexual minorities. ${ }^{230}$ In analyzing the third factor, the court in Witt concluded that Lawrence must have required heightened scrutiny because it cited and relied on heightened scrutiny case law in its opinion. ${ }^{231}$ Because Windsor relies on one rational basis case and two heightened scrutiny cases, this factor is not dispositive, yet was found to suggest the Court's application of heightened scrutiny. ${ }^{232}$

After applying the three factors set forth by the Ninth Circuit in Witt, the SmithKline court concluded that Windsor requires careful consideration of the actual purposes and resulting effects of laws that discriminate on the basis of sexual orientation in order to ensure that courts neither send nor reaffirm messages that stigmatize members of the LGBT community. ${ }^{233}$ Although Witt was decided on the grounds of due process, rather than equal protection, the Ninth Circuit's parallel interpretation supports applying heightened scrutiny to sexual orientation classifications under the Equal Protection Clause as well. ${ }^{234}$

The Eighth Circuit, in Ehrmann, and the Eleventh Circuit, in Sneed, have taken the opposite position, expressing serious doubt that the scope of Batson extends beyond race and gender. ${ }^{235}$ In Ehrmann, the defendant was charged with various crimes relating to the possession and distribution of methamphetamine and ecstasy. ${ }^{236}$ Ehrmann raised a Batson challenge during jury selection on the grounds that the government struck a potential juror because of his sexual orientation. ${ }^{237}$ The district court denied the challenge, questioning Batson's applicability to sexual orientation. ${ }^{238}$ The court noted that neither the United States Supreme Court, nor the Eighth Circuit, had ever held that sexual orientation qualifies as a protected class under Batson. ${ }^{239}$ The court therefore refused to interpret Batson in a manner that extended to sexual orientation. ${ }^{240}$ Accordingly, the Eighth Circuit held that peremptory challenges based solely on sexual orientation may not be

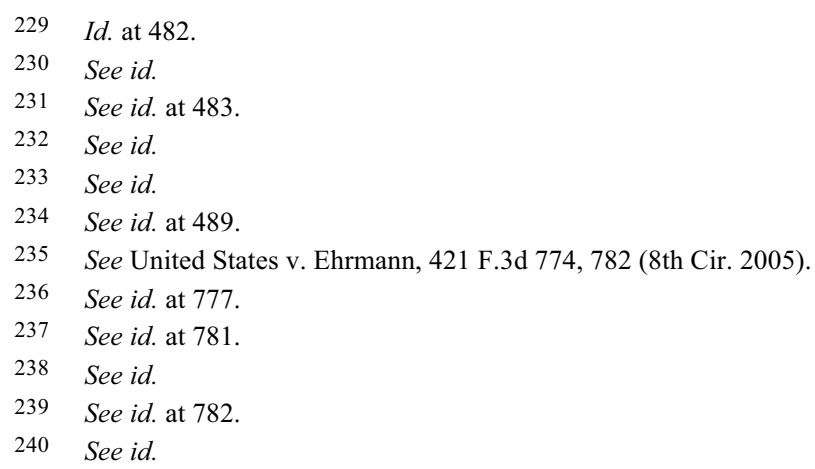


challenged under the Batson standard. ${ }^{241}$

In Sneed, the defendant appealed from the denial of his habeas petition. ${ }^{242} \mathrm{He}$ argued that he had ineffective assistance of counsel because his attorney failed to object to the exclusion of homosexuals from the venire and petit jury. ${ }^{243}$ The Eleventh Circuit held that Sneed did not demonstrate that homosexuals were underrepresented and, therefore, failed to make his discriminatory jury selection claim under the Equal Protection Clause of the Fourteenth Amendment. ${ }^{244}$ The court further noted that the defendant failed to provide any evidence regarding the sexual orientation of the members of the jury pool and how many homosexuals, if any, were among the venire or petit jury. $^{245}$

The Ninth Circuit reached the correct decision and all circuits should unanimously adopt its analysis. Based on its explicit reading of Windsor as authorizing heightened scrutiny for classifications based on sexual orientation, it logically follows that the Batson analysis should extend to peremptory challenges based on sexual orientation. ${ }^{246}$ Sexual minorities have experienced a history of discrimination and exclusion and, therefore, should be afforded the same protections as individuals who are discriminated against based on their race and gender during voir dire. ${ }^{247}$

Although the Eighth and Eleventh Circuits declined to extend Batson to discrimination based on sexual orientation, they did not provide any rationale for doing so, aside from the fact that the Supreme Court has not yet held that sexual orientation qualifies as a protected class under Batson. ${ }^{248}$ Scholars have argued, however, that "[n]othing in the decisions of Batson or J.E.B. indicates that the Court intends to limit equal protection rights against improper exclusion from jury service to strikes motivated by race and gender - these are simply the only issues the Court has chosen to address directly." 449 Because the Supreme Court has not articulated whether Batson prohibits discrimination based on sexual orientation, the trend of lower courts applying heightened scrutiny to sexual orientation classifications should guide this analysis. ${ }^{250}$

\footnotetext{
241 See id.

242 See Sneed v. Fla. Dep't of Corr., 496 F. App'x 20, 22 (11th Cir. 2012).

244 See id. at 27.

245 See id.

246 See generally SmithKline Beecham Corp. v. Abbott Labs., 740 F.3d471 (9th Cir. 2014).

247 See Claus, supra note 110, at 168-69.

248 See United States v. Ehrmann, 421 F.3d 774, 782 (8th Cir. 2005).

249 Elaine A. Carlson, Batson, J.E.B., and Beyond: The Paradoxical Quest for Reasoned Peremptory Strikes in the Jury Selection Process, 46 BAYLOR L. REV. 947, 967 (1994).

250 See, e.g., In re Marriage Cases, 43 Cal. 4th 757, 844 (2008); Varnum v. Brien, 763 N.W.2d 862, 896 (Iowa 2009); Griego v. Oliver, 316 P.3d 865, 884 (N.M. 2013).
} 


\section{B. Extending Batson to Sexual Orientation}

Sexual orientation discrimination should be prohibited under the Batson analysis because it is a form of gender discrimination, which is already barred by the Court's decision in J.E.B. ${ }^{251}$ By definition, if conduct is prohibited when engaged in by a person of one gender, yet is acceptable when engaged in by a person of the opposite gender, then such a prohibition is discriminatorily based on gender. ${ }^{252}$ This type of discrimination occurs regularly when members of the LGBT community engage in conduct that, but for their gender, would be tolerated by society. ${ }^{253}$ Take, for example, the issue of same-sex marriage that has recently attracted a significant amount of legal attention. ${ }^{254}$ While a man and a woman are permitted to marry each other, until recently, the same conduct was prohibited when engaged in by two men or two women. ${ }^{255}$ Homosexual and transgender individuals have been discriminated against because their sexual preferences do not conform to society's view of traditional gender roles. ${ }^{256}$ The Court has held that the constitutional command forbidding intentional exclusion applies to any cognizable group in the community that may be the subject of prejudice. ${ }^{257}$

The LGBT community has experienced a well-documented history of purposeful discrimination and has long been a politically powerless group, which is evinced by the passage and enforcement of many statutes and policies that have stripped them of rights as individuals. ${ }^{258}$ Some historical examples of discrimination based on sexual orientation include denial of the fundamental right to marry and employment protection under the law. ${ }^{259}$ While the prejudicial attitudes toward race and gender have not been identical to those toward sexual minorities, the similarities between such experiences outweigh the differences. ${ }^{260}$ The Court has held that all individuals, when selected to serve on a jury, have the right not to be removed solely based on discriminatory and stereotypical reasons that serve to perpetuate patterns of historical discrimination. ${ }^{261}$ The LGBT community

251 See J.E.B. v. Alabama ex rel. T.B., 511 U.S.127 (1994).

252 See Koppelman, supra note 21, at 208.

253 See id.

254 See generally United States v. Windsor, 133 S. Ct. 2675 (2013); Obergefell v. Hodges, 135 S. Ct. 2584 (2015).

255 See id.

256 See Sandi Farrell, Reconsidering the Gender-Equality Perspective for Understanding LGBT Rights, 13 LAW \& SEXUALITY 605, 619 (2004).

257 See Swain v. Alabama, 380 U.S. 202, 204-05 (1965), overruled by Batson v. Kentucky, 476 U.S. 79 (1986).

258 See Claus, supra note 110, at 168-69.

259 See id. at 161-62, 169.

260 See J.E.B. v. Alabama ex rel. T.B., 511 U.S. 127, 135 (1994).

261 See id. at $141-42$. 
is undoubtedly an identifiable group that has been the subject of discrimination throughout history and, therefore, deserves the same protections that are afforded to victims of discrimination on the basis of race and gender. ${ }^{262}$

Even if the Court determines that sexual orientation discrimination is not a form of gender discrimination, Batson should still apply to sexual orientation discrimination because the similarities between gender and sexual orientation discrimination support the extension of Batson to the latter class. $^{263}$ Additionally, the implications of Windsor subjecting classifications based on sexual orientation to heightened judicial review support allowing Batson challenges on the basis of sexual orientation. ${ }^{264}$

The parallels between discrimination on the basis of gender and discrimination on the basis of sexual orientation are striking. ${ }^{265}$ Both types of discrimination are rooted in the same presumption-that traditional gender roles should be enforced. ${ }^{266}$ As the LGBT community has become more visible in society, they have undeniably experienced the same type of discrimination that women have experienced throughout history. ${ }^{267}$ These individuals have experienced difficulties entering various professions, including the military, police or fire departments, medicine, law, and business. ${ }^{268}$ According to stereotypical gender roles, gay men have been expected to undertake careers in cosmetics and fashion, while lesbians have been excluded from the workforce and expected to fulfill their role as homemakers. ${ }^{269}$ Similar to discrimination based on gender, sexual orientation discrimination is based on the preconceived gender role to which an individual is expected to conform. ${ }^{270}$

Much like discrimination based on gender, discrimination based on sexual orientation is a recent phenomenon because it is becoming more socially acceptable for individuals to openly acknowledge their sexual preferences, without fear of being completely ostracized from society. ${ }^{271}$ Historically, individuals of the LGBT community would remain silent regarding their sexual preferences, which was rarely a matter of inquiry during voir dire, because of the stigmatization surrounding sexual

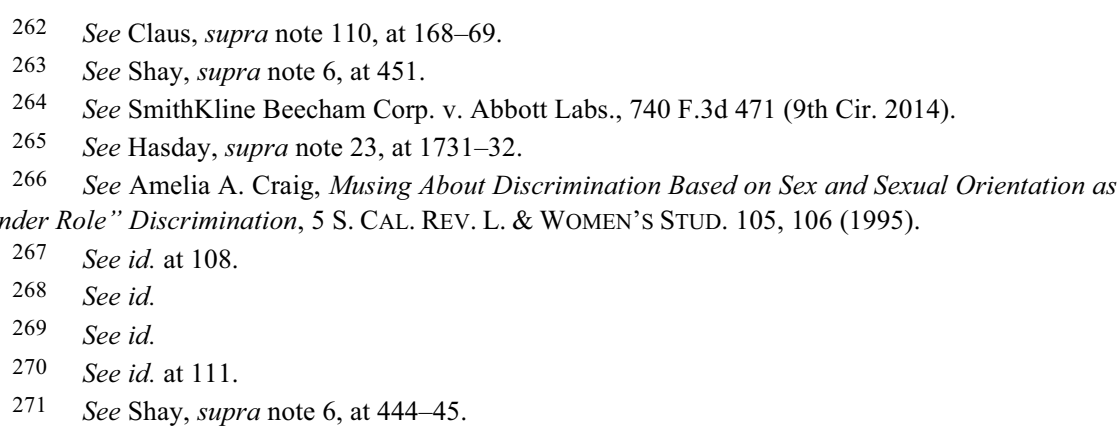


minorities. ${ }^{272}$ In recent years, however, some states have passed antidiscrimination provisions to protect the LGBT community, and the public opinion regarding LGBT issues has become progressively supportive. ${ }^{273}$ Over time, sexual minorities have become less fearful of discrimination; therefore, discussions regarding sexual orientation during voir dire are becoming increasingly commonplace. ${ }^{274}$

Another similarity between gender and sexual orientation is that both are immutable characteristics, requiring additional protection from discrimination. ${ }^{275}$ While some debate continues over the immutability of sexual orientation, courts have acknowledged that individuals do not choose their sexual preferences and should not be subjected to discrimination on such a basis. ${ }^{276}$ In Watkins v. U.S. Army, the Ninth Circuit concluded that, "sexual orientation is immutable for the purposes of the equal protection doctrine. Although the causes of homosexuality are not fully understood, scientific research indicates that we have little control over our sexual orientation and that, once acquired, our sexual orientation is largely impervious to change." 277 Accordingly, the reasoning of J.E.B., which prohibits peremptory strikes exclusively based on gender, should similarly forbid deliberate discrimination solely based on sexual orientation. ${ }^{278}$

In addition to the overwhelming parallels between gender and sexual orientation, both classes are subject to a heightened standard of judicial review. ${ }^{279}$ The Court in Windsor, while not expressly stating the level of judicial review it was applying, implicitly adopted heightened scrutiny for classifications based on sexual orientation. ${ }^{280}$ The Court noted that discrimination of such an unusual character requires careful consideration in determining whether a law is motivated by an improper purpose. ${ }^{281}$ In addition to its interpretation of the Supreme Court's decision in Windsor, the Ninth Circuit considered whether the relevant class has historically been excluded from jury service and whether that class has suffered from invidious group stereotypes. ${ }^{282}$ The Ninth Circuit's reading of Windsor

272 See id. at 416.

273 See id. at 411.

274 See id.

275 See e.g., Watkins v. United States Army, 847 F.2d 1329, 1347 (9th Cir. 1988), opinion withdrawn on reh'g, 875 F.2d 699 (9th Cir. 1989).

276 See, e.g., id.

277 Id.

278 See J.E.B. v. Alabama ex rel. T.B., 511 U.S. 127, 129 (1994).

279 See generally SmithKline Beecham Corp. v. Abbott Labs., 740 F.3d471 (9th Cir. 2014); see also United States v. Windsor, 133 S. Ct. 2675 (2013).

280 See Windsor, 133 S. Ct. at 2693.

281 See id. (emphasis added).

282 See SmithKline, 740 F.3d at 471. 
resulted in its conclusion that the Supreme Court mandated that classifications based on sexual orientation be subject to heightened scrutiny. ${ }^{283}$ Because both gender and sexual orientation classifications are subject to heightened judicial review, the rationale of Windsor suggests that the Batson analysis should also be extended to peremptory strikes based on sexual orientation. ${ }^{284}$

Windsor represents the beginning of the Supreme Court's review of classifications that discriminate based on sexual orientation. As the area of sexual orientation discrimination continues to evolve in the legal field, the Court will, once again, be confronted with determining the standard of judicial review for sexual orientation classifications. ${ }^{285}$ Based on the parallels between gender and sexual orientation as identifiable classes, it is likely that the Court will explicitly hold that the standard of review for sexual orientation classifications is heightened scrutiny. ${ }^{286}$ Gender, like sexual orientation, was originally subject to rational basis review, before evolving into heightened scrutiny. ${ }^{287}$ If history is any indication of the future, the Court's sexual orientation equal protection jurisprudence is likely to develop into explicit application of heightened judicial review.

While the similarities between gender and sexual orientation support extending Batson to sexual orientation, there is one fundamental difference that must be addressed - race and gender can typically be observed during voir dire, while sexual orientation generally requires specific inquiry to ascertain. ${ }^{288}$ LGBT identity is often not readily apparent and, therefore, identifying anti-gay bias differs significantly from identifying racial or gender bias. ${ }^{289}$ The Supreme Court has held, however, that minor differences between classes do not overpower the similarities between the experiences they have shared. ${ }^{290}$

The differences between sexual orientation discrimination and discrimination on the basis of race or gender raise the question of whether inquiry into a person's sexual orientation is appropriate during voir dire. Some courts have taken the position that it is never appropriate to inquire into a person's sexual orientation during voir dire. ${ }^{291}$ While judges have broad discretion in determining the scope of questioning, "the purpose of the voir dire is to ascertain disqualifications, not to afford individual

$\begin{array}{ll}283 & \text { See id. } \\ 284 & \text { See generally id. } \\ 285 & \text { See Lynd, supra note 101, at } 286 . \\ 286 & \text { See id. } \\ 287 & \text { See id. } \\ 288 & \text { See Shay, supra note 6, at 445. } \\ 289 & \text { See id. at 426. } \\ 290 & \text { See J.E.B. v. Alabama ex rel. T.B., 511 U.S. 127, } 135(1994) . \\ 291 & \text { See People v. Garcia, } 77 \text { Cal. App. 4th 1269, 1280 (2000). }\end{array}$


analysis in depth to permit a party to choose a jury that fits into some mold that he believes appropriate for his case. ${ }^{, 292}$ Overall, there is not a consensus among courts regarding the permissibility of inquiring into potential jurors' sexual orientation during voir dire. ${ }^{293}$ Courts have generally agreed, however, that individuals are entitled to some degree of privacy when they are summoned for jury service. ${ }^{294}$ As such, inquiring into a prospective juror's sexual orientation is likely prohibited when the information is not essential to the case or when there are other, less intrusive methods of ascertaining juror bias or impartiality. ${ }^{295}$

While some scholars have argued that the practical implications of expanding Batson to include classifications based on sexual orientation may lead to difficulties in preserving jurors' equal protection and privacy rights, the primary interests at stake are, and must continue to be, those of the defendant. $^{296}$ Although, as mentioned above, there are some intrinsic differences between race and gender-based discrimination during voir dire, such differences do not overpower the similar experiences they have shared. ${ }^{297}$ While some have proposed that individual state court rules may be amended to prohibit discrimination based on sexual orientation during voir dire, this solution does not adequately protect the LGBT community, as the extension of Batson would. ${ }^{298}$

\section{CONCLUSION}

Batson should be extended to sexual orientation discrimination because it is simply a form of gender discrimination. ${ }^{299}$ Alternatively, the parallels between gender and sexual orientation support extending Batson to sexual orientation discrimination during voir dire. ${ }^{300}$ Furthermore, the Court's decision in Windsor, which applied heightened scrutiny to classifications based on sexual orientation, supports extending Batson to such classifications. ${ }^{301}$ For these reasons, peremptory strikes based on sexual orientation violate the Equal Protection Clause and may be challenged under Batson. ${ }^{302}$

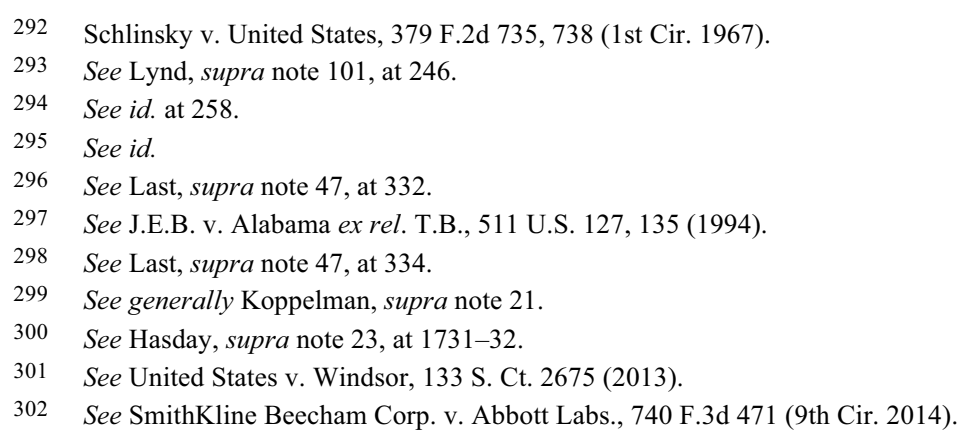


Relying on the reasoning of Batson and the equal protection analysis in Windsor, the Ninth Circuit correctly held that peremptory strikes used to discriminate on the basis of sexual orientation may be challenged under Batson. ${ }^{303}$ Much like race and gender, a party may establish a prima facie case of purposeful discrimination on the basis of sexual orientation by showing that he or she is a member of a cognizable group that is subject to discrimination and that the opposing party exercised their peremptory challenges to remove members of that cognizable group. ${ }^{304}$ The striking party would then be required to offer a neutral, nondiscriminatory explanation for challenging those jurors. ${ }^{305}$ The court would ultimately determine, based on the record, whether the challenging party has made a showing of purposeful discrimination. ${ }^{306}$

If Batson is not expanded to prohibit sexual orientation discrimination during voir dire, it will harm the litigants, excluded jurors, and community as a whole. ${ }^{307}$ The Supreme Court has held that "with the exception of voting, for most citizens the honor and privilege of jury duty is their most significant opportunity to participate in the democratic process.",308 Permitting parties to exercise peremptory challenges discriminatorily based on an individual's sexual orientation will deprive ordinary citizens of the opportunity to participate in the judicial system and may result in a loss of respect for the law. ${ }^{309}$

Although discrimination on the basis of religion and national origin are beyond the scope of this Note, the arguments presented in support of expanding Batson to include sexual orientation discrimination raise potential implications for other classifications. In order to preserve the equal protection right of prospective jurors to participate in the administration of justice, striking jurors of other identifiable classes that are subject to strict or heightened scrutiny should be impermissible as well. ${ }^{310}$ The United States Code Annotated provides that "[n]o citizen shall be excluded from service as a grand or petit juror in the district courts of the United States or in the Court of International Trade on account of race, color, religion, sex, national origin, or economic status." 311 Based on this provision, Batson would likely apply to discrimination on the basis of

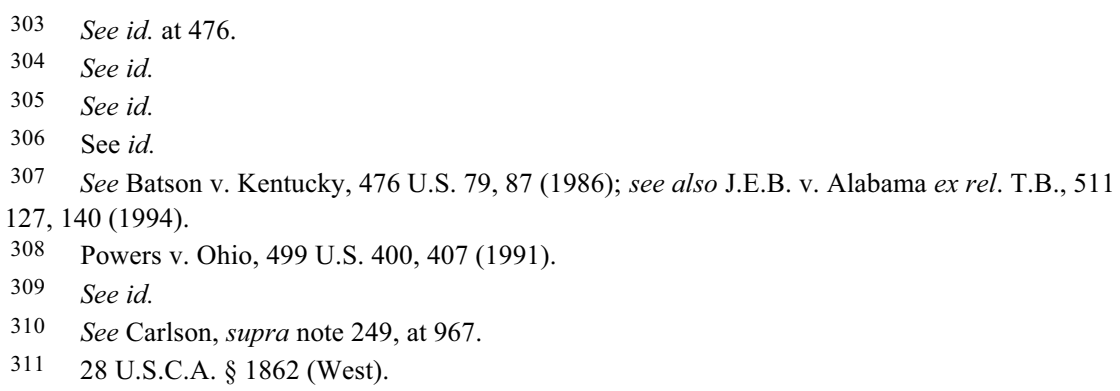


religious affiliation during voir dire. ${ }^{312}$ Some scholars have argued that the free exercise of religion is a fundamental right and, thus, should be subject to strict scrutiny. ${ }^{313}$ Based on this argument, because religion-based peremptory challenges are not narrowly tailored and rely on stereotypical assumptions, they violate strict scrutiny and should be eliminated under the Batson standard as well. ${ }^{314}$

The Supreme Court has suggested that the Batson analysis may also apply to peremptory challenges based solely on an individual's ethnicity or national origin. ${ }^{315}$ In Hernandez v. New York, the Supreme Court noted that if the prosecutor exercised a peremptory challenge to exclude Latinos or Hispanics from the jury solely based on their ethnicity, the strike would constitute a violation of the Equal Protection Clause. ${ }^{316}$ The Court's dicta suggests that the Batson analysis also extends to peremptory challenges based exclusively on an individual's ethnicity or national origin. ${ }^{317}$ The Court explained that for certain ethnic groups, "proficiency in a particular language, like skin color, should be treated as a surrogate for race under an equal protection analysis." 318

In his second inaugural address, President Obama recognized that the civil rights movement for racial equality, the women's rights movement, and the gay rights movement are all fundamental to the achievement of equality in America. ${ }^{319}$ Each of the aforementioned social movements involve overlapping principles that are rooted in the Constitution and the Declaration of Independence. ${ }^{320}$ As such, classifications that single out individuals from each of these cognizable groups for disparate treatment should be afforded the same protections under the law. ${ }^{321}$

312 See Benjamin Hoorn Barton, Religion-Based Peremptory Challenges After Batson v. Kentucky and J.E.B. v. Alabama: An Equal Protection and First Amendment Analysis, 94 MicH. L. REV. 191, 209 (1995).

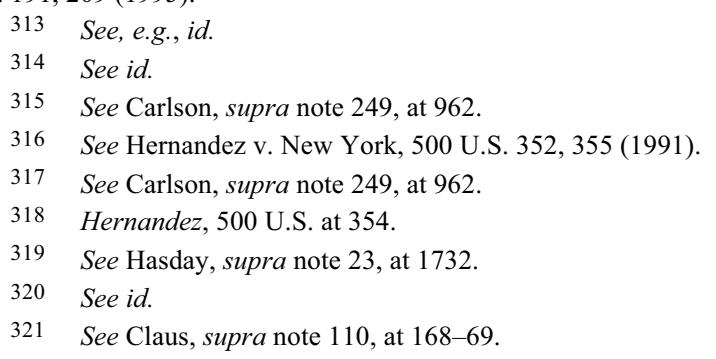

